\title{
Influence of Ureolytic Bacteria Toward Interlocking Compressed Earth Blocks (ICEB) in Improving Durability of ICEB
}

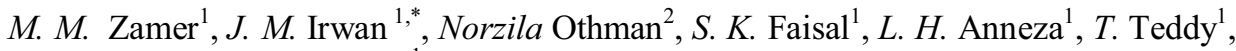 \\ and Abdullah Faisal Alshalif ${ }^{1}$ \\ ${ }^{1}$ Jamilus Research Centre for Sustainable Construction (JRC), Faculty of Civil and Environmental \\ Engineering, Universiti Tun Hussein Onn Malaysia, 86400, Parit Raja, Johor, Malaysia \\ ${ }^{2}$ Micro-Pollutant Research Centre (MPRC), Faculty of Civil and Environmental Engineering, \\ University Tun Hussein Onn Malaysia, 86400, Parit Raja, Johor, Malaysia
}

\begin{abstract}
Interlocking compressed earth blocks (ICEB) are soil stabilized based blocks that allows for mortarless construction. Various studies have been conducted to improve the durability of bricks by using environmental friendly solution. This is because common method used by the construction industries generally involving the use of chemical based substances which will promote pollution to the surrounding. This paper provide the results of Ureolytic Bacteria (UB) in improving the compressive strength and water absorption properties with the percentage of $1 \%, 3 \%$ and $5 \% \mathrm{UB}$ for $7^{\text {th }}, 14^{\text {th }}$ and $28^{\text {th }}$ days of testing. The bacteria were added as partial replacement of limestone water in ICEB. The results of compressive strength and water absorption show that the increment of $15.25 \%$ strength and reduction of $15.66 \%$ water absorption with $5 \%$ of UB on the $28^{\text {th }}$ days of testing compared to the control specimen. Therefore it is hoped that the positive results on using bacteria will continue to improve the durability of the ICEB as one of the environmental friendly solution in order to achieve sustainable construction.
\end{abstract}

\section{Introduction}

Interlocking compressed earth block (ICEB) is a cost effective, dry stacked (mortarless) and sustainable construction material which has potential to bring durable and affordable homes to developing countries around the world [1]. Generally ICEB will give illustration of a block that is made up of earth-based material that has been going through a compression process [2]. ICEBs are often chosen because the blocks does not required to be burnt, thus reduce the emission of carbon dioxide. On the other hand, the production from conventional building construction materials pollutes the air, water and land [3]. The production of ICEBs also faster, easier and effective as compared to conventional blocks [4]. These advantages make ICEB practical and preferred construction form.

* Corresponding author: irwan@uthm.edu.my 
Previous studies had taken different approach to improve the properties of construction material by introducing the used of bacteria. Researcher such as Willem et al [5] used Bacillus sphaericus, Navdeep et al [6] used Bacillus megaterium, Abhjit et al [7] used Bacillus megaterium and Bernardi et al [8] used Sporosarcina paseurii. All bacteria used by previous studies resulted in increasing on compressive strength and reduction on water absorption by comparing control sample and treated sample with bacteria. Positive results from previous studies indicated that the successfulness of using bacteria as an environmental friendly solution in improving the durability of construction material [9]. According to Siddique [10], bacteria are able to promote the precipitation of calcium carbonate $\left(\mathrm{CaCo}_{3}\right)$ in the form of calcite. The calcite will fill all pores which prevent water ingression. Deposition of calcium carbonate layer on the surface area resulted to decrease water absorption and porosity [10]. Hence it will improve the durability of the material properties.

The understanding on fundamental precipitation calcium carbonate $\left(\mathrm{CaCo}_{3}\right)$ had been applied in this research with the use of ureolyric bactreria (UB) to improve the durability of ICEB.

\section{Methodology}

\subsection{Enrichment of bacteria}

The purpose of enrichment process was to obtain growth curve for the ureolytic bacteria to ensure the survivability of UB in ICEB environment. Two set of enrichment were prepared namely control and treatment specimen. The composition of the treatment enrichment consist of $300 \mathrm{ml}$ nutrient broth added with $120 \mathrm{ml}$ of $40 \%$ urea added also with $1 \mathrm{mg}$ of soil substances and lastly 1 cyrogenic bead of ureolytic bacteria. The differences between the compositions of control were the enrichment was done without the soil sample. The method follows the previous study, Irwan [11] by adjusting the $\mathrm{pH}$ in alkaline and anaerobic condition were attempt for ensuring the survival of ureolytic bacteria.

\subsection{Production of ICEB}

The production process of ICEB is a critical element and should be handled very well in order to maintain the quality of the specimen. The materials used to produce the ICEB specimen are soil, sand, cement and limestone water. The addition of bacteria acts as partial replacement of limestone water. Fig. 1 shows the material that has been weight and ready to be mixed. Then the material must first be mixed thoroughly in ICEB mixer. The limestone water and ureolytic bacteria (UB) were added after the mixture are well mix and goes straight to the ICEB mold as shown in Fig. 2. Hydraulic machine was used to compress the mold to form the ICEB specimen. Fig. 3 shows the process of compressing specimen to produce interlocking compressed earth block (ICEB).

\subsection{Compressive strength}

The compressive strength $(f c)$ was determined by using ICEB block $(100 \times 125 \times 250 \mathrm{~mm})$ specimen and the strength are measured for $7^{\text {th }}, 14^{\text {th }}$ and $28^{\text {th }}$ days. There are four set batches of ICEB represented by control, 1\%, 3\% and 5\% of UB which was partially replaced of limestone water for ICEB production. All batches were tested in triplicates and the average results of these triplicates are presented and discussed. The test was carried out according to the BS 3921:1985, [12] which specify for the testing of bricks. 


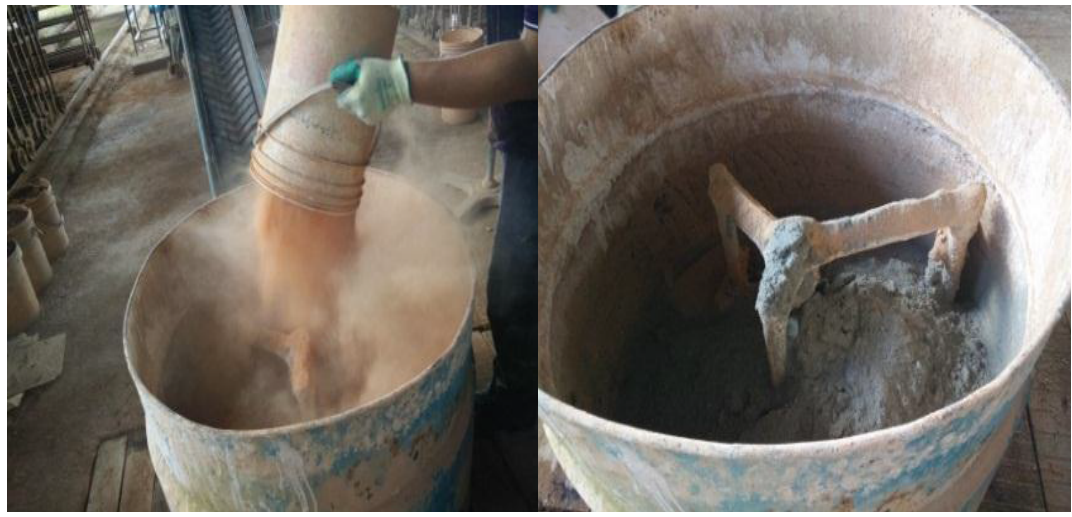

Fig. 1. Mixing of laterite soil, sand and cement for production of ICEB.

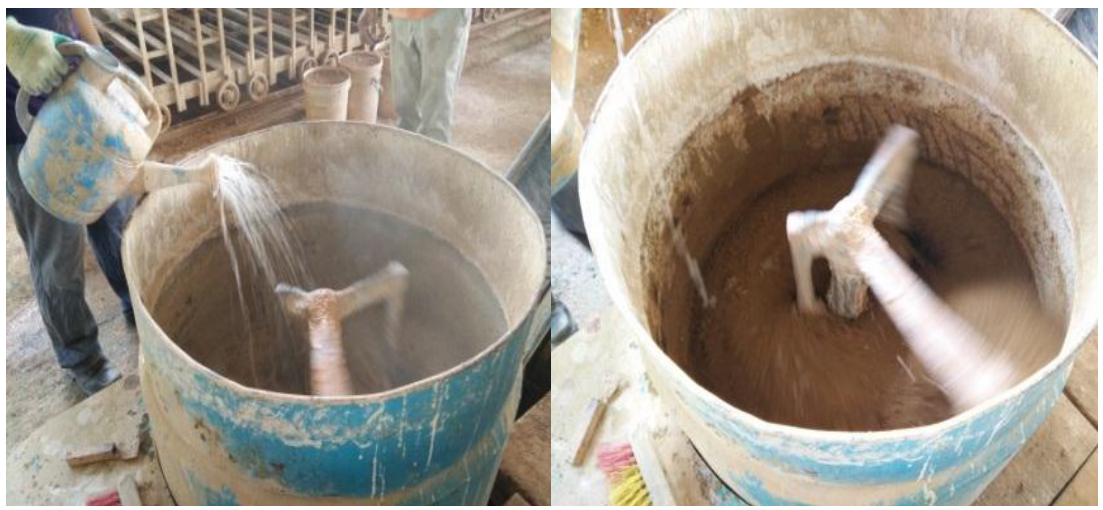

Fig. 2. Addition of limestone water and ureolytic bacteria (UB).

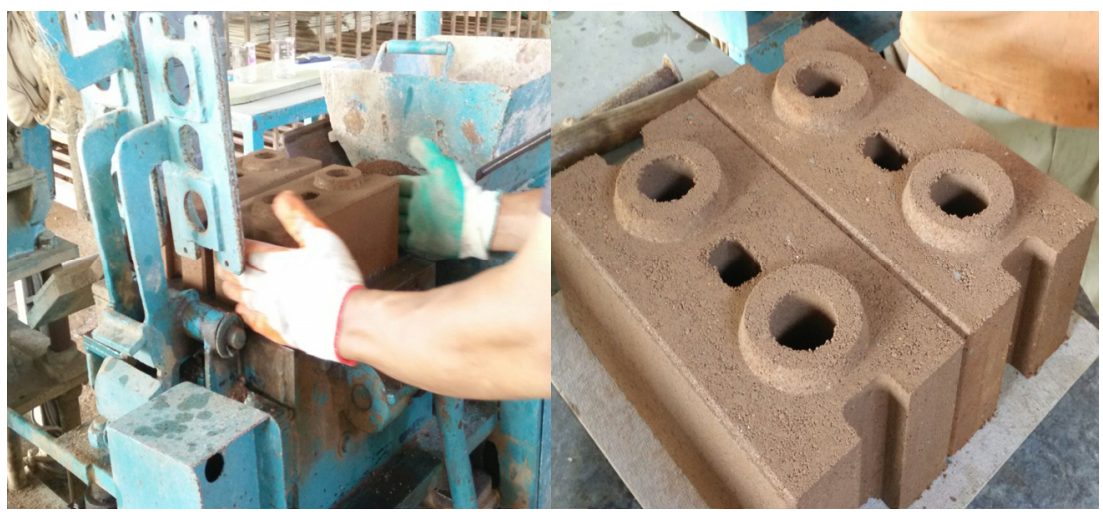

Fig. 3. Production of ICEB specimen. 


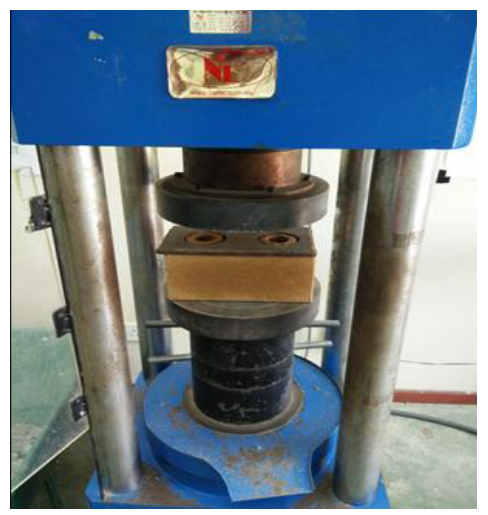

Fig. 4. Compressive strength test of ICEB.

\subsection{Water absorption}

The water absorption test was conducted to determine the percentage of water absorbed by the bacterial ICEB by monitoring changes in weight among the ICEB with and without bacteria. The test also determined the saturation coefficient which is defined as the percentage of pore volume filled in 24-hour of soaking. The tests are conducted for $7^{\text {th }}, 14^{\text {th }}$ and $28^{\text {th }}$ days. The test was carried out also according to the BS 3921-1985, [12] which specify for standard specification for clay masonry units.

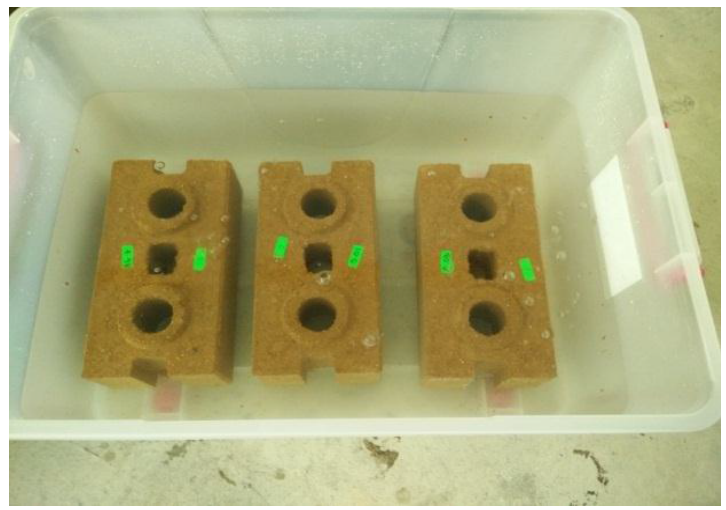

Fig. 5. Water absorption test of ICEB at 24-hour submersion.

\section{Results and discussion}

\subsection{Compressive strength}

Table 1 and Fig. 4 show the results on compressive strength with time. The compressive strength of ICEB specimen with bacteria increased gradually for 7th, 14th and 28th days of testing compared to the control specimen. The addition of UB with liquid culture of $1 \%$, $3 \%$ and $5 \%$ in ICEB increased the compressive strength within time compared to control specimen. The patterns of compressive strength increment are the same for all UB addition. The highest compressive strength recorded was $6.35 \mathrm{~N} / \mathrm{mm}^{2}$ at the $28^{\text {th }}$ days of testing for $5 \%$ addition of UB. 
The positive result indicates the successfulness of UB in deposition of calcium carbonate, $\mathrm{CaCO}_{3}$ for enhancement the strength of ICEB. The increment of compressive strength with added bacteria agreed with Navdeep [6] studies which state that compressive strength can be significantly increased by application of bacteria calcite.

Table 1. Results on compressive strength.

\begin{tabular}{|c|c|c|c|}
\hline \multirow{2}{*}{$\begin{array}{c}\text { Specimen with } \\
\text { UB }\end{array}$} & \multicolumn{3}{|c|}{ Compressive Strength $\left(\mathbf{N} / \mathbf{m m}^{\mathbf{2}}\right)$} \\
\cline { 2 - 4 } & $\mathbf{7}^{\text {th }}$ day & $\mathbf{1 4}^{\text {th }} \mathbf{d a y}$ & $\mathbf{2 8}^{\text {th }}$ day \\
\hline $0 \%($ Control $)$ & 2.24 & 4.50 & 5.51 \\
\hline $1 \%$ & 3.05 & 4.79 & 6.10 \\
\hline $3 \%$ & 2.79 & 4.68 & 6.30 \\
\hline $5 \%$ & 2.76 & 4.75 & 6.35 \\
\hline
\end{tabular}

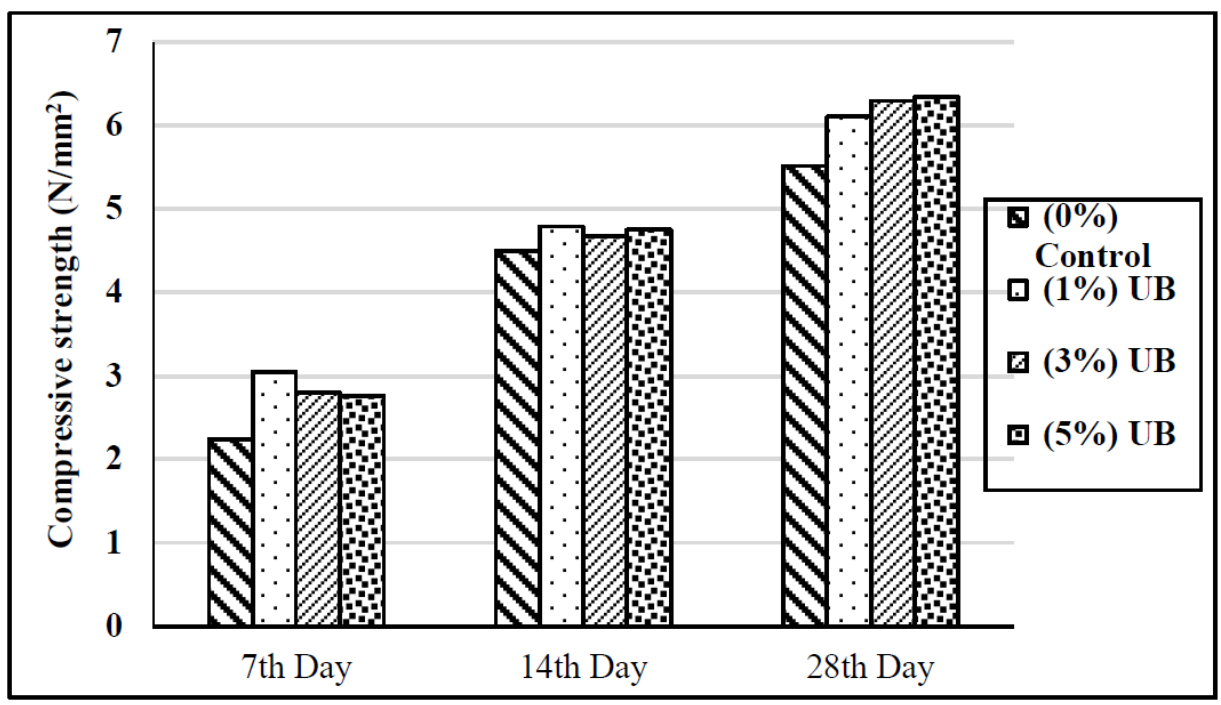

Fig. 4. Relationship between compressive strength and time.

\subsection{Water absorption}

Table 2 and Fig. 5 show the results on water absorption with time. The percentage of water absorption for $5 \%$ addition UB on the $28^{\text {th }}$ days of testing achieved the lowest percentage compared to other ICEB specimen which is $7.70 \%$. The reduction patterns of water absorption percentage are the same for all UB addition (1\%, 3\% and 5\%).

The positive results also indicated the successfulness of UB in depositing calcium carbonate, $\mathrm{CaCo}_{3}$ as calcite in filling the pores to prevent ingress of water absorption. According to Abhjit [7], the calcite crystal act as biosealant by filling the pores which leads to reduction in water absorption, porosity, permeability and enhance the strength of the bricks. Therefore the results on reduction of water absorption collated with studies that was done by Abhjit [7]. 
Table 2. Results on water absorption.

\begin{tabular}{|c|c|c|c|}
\hline \multirow{2}{*}{$\begin{array}{c}\text { Specimen with } \\
\text { UB }\end{array}$} & \multicolumn{3}{|c|}{ Water Absorption (\%) } \\
\cline { 2 - 4 } & $\mathbf{7}^{\text {th }}$ day & $\mathbf{1 4}^{\text {th }}$ day & $\mathbf{2 8}^{\text {th }}$ day \\
\hline$(0 \%)$ Control & 9.81 & 9.27 & 9.13 \\
\hline$(1 \%)$ & 9.71 & 8.77 & 8.10 \\
\hline$(3 \%)$ & 9.23 & 8.69 & 8.05 \\
\hline$(5 \%)$ & 8.73 & 8.13 & 7.70 \\
\hline
\end{tabular}

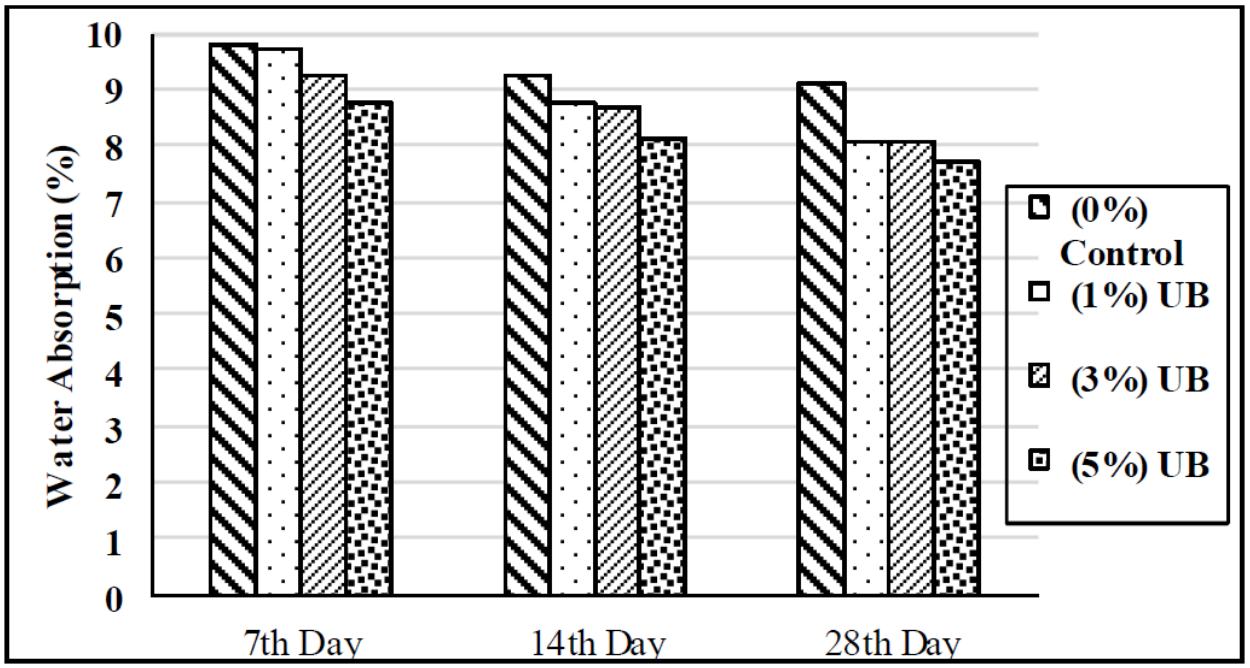

Fig. 5. Relationship between water absorption and time.

\section{Conclusion}

The results from both compressive strength and water absorption tests show the successfulness of UB in depositing calcium carbonate, $\mathrm{CaCo}_{3}$. Addition of $\mathrm{UB}$ in ICEB presents the increment in strength and reduction on absorption of water. The $5 \%$ addition of UB in ICEB indicates the best result which achieved highest increment in strength with $15.25 \%$ and highest reduction of water absorption with $15.66 \%$ at the $28^{\text {th }}$ days of testing. Further study should be conducted through various engineering properties and microstructure testing in order to determine the influence and morphology of UB in ICEB.

This research was supported by Universiti Tun Hussein Onn Malaysia (UTHM), Malaysia, The Ministry of Higher Education Malaysia through Fundamental Research Grant Scheme (FRGS), Vot. 1577 and collaboration with ICEB industry IRYAS INC. (M) Sdn Bhd.

\section{References}

[1] P.T. Laursen, N.A. Herskedal, D.C. Jansen and B. Qu, Interlocking Compressed Earth Blocks Walls: Out-of-Plane Structural Response, 15th World Conference On Earthquake Engineering, Lisbon, Portugal, 71-81, (2012) 
[2] F.V. Riza and I.A. Rahman, The Properties of Compressed Earth-Blocks (CEB) Masonry Blocks, J. Eco-efficient Masonry Bricks and Blocks: Design, Properties and Durability, 17, 379- 392, (2014)

[3] N. Ali, N.A. Zainal, M.K. Burhanudin, A.A.A. Samad, N. Mohamad, S. Shahidan and S.R. Abdullah, Physical and Mechanical Properties of Compressed Earth Brick (CEB) Containing Sugarcane Bagasse Ash, MATEC Web of Conferences, 47, 1-7, (2016)

[4] F.V. Riza, I.A. Rahman and A.M.A. Zaidi, A brief review of compressed stabilized earth brick (CSEB), Int. Conference on Science and Social Research, Kuala Lumpur, Malaysia, 999-1004, (2010)

[5] W. De Muynck, D. Debrouwer, N. De Belie and W. Verstraete, Bacterial carbonate precipitation improves the durability of cementitious materials, J. of Cement and Concrete Research, 38(7), 1005-1014, (2008)

[6] N.K. Dhami, M.S. Reddy and A. Mukherjee, Improvement in strength properties of ash bricks by bacterial calcite, J. of Ecological Engineering, 39, 31-35, (2012)

[7] A. Mukherjee, N.K. Dhami, B.V.V Reddy and M.S. Reddey, Bacterial Calcification for Enhancing Performance of Low Embodied Energy Soil-Cement Bricks, Third Int. Conference on Sustainable Construction Materials and Technology, Kyoto, Japan, (2013)

[8] D. Bernadi, J.T. Dejong, B.M. Montoya and B.C. Mattinez, Bio-bricks: Biologically cemented sandstone bricks, J. of Construction and Building Material, 55, 462-469, (2014)

[9] J.M. Irwan, M.M Zamer and N. Othman, A Review on Interlocking Compressed Earth Blocks (ICEB) with Addition of Bacteria, MATEC Web of Conferences, 47, 1-5, (2016)

[10] R. Siddique and N.K. Chahal, Effect of ureolytic bacteria on concrete properties, J. of Construction and Building Materials, 25(10), 3791-3801, (2011)

[11] J.M. Irwan, L.H. Anneza, N. Othman, T. Husnul and A.F.Alshalif, Isolation and Identification of Concrete Environment bacteria, IOP Conference Series: Materials Science and Engineering, 136(1), 1-9, (2016)

[12] British Standard 3291, Specification for Clay Bricks, British Standard Institution, London, United Kingdom, (1985) 